\title{
APPLICATION OF TQM IN THE CONSTRUCTION INDUSTRY OF DEVELOPING COUNTRIES - CASE OF TURKEY
}

\author{
Anas Attellah Ali SHOSHAN ${ }^{1}$, Gözde TANTEKİN ÇELIK ${ }^{2, *}$ \\ ${ }^{1}$ Civil Engineering, College of Engineering, Kirkuk University, Kirkuk, Iraq \\ ${ }^{2}$ Civil Engineering, Engineering Faculty, ÇukurovaUniversity, Adana, Turkey
}

\begin{abstract}
In this study, a questionnaire survey was developed in order to investigate the application of TQM in Turkish construction industry and identify the critical success factors, barriers, and benefits of this application. The questionnaire was completed by 32 firms. The results of the study revealed that there are short comings in TQM application in Turkish construction industry especially in relation to top management commitment and leadership; the greatest benefit of TQM to the firms is 'increased customer satisfaction'.
\end{abstract}

Keywords: Quality, Total quality management, TQM; Turkish construction industry, Customer satisfaction

\section{INTRODUCTION}

Rapid technological development is leading to expansion of the mass production and increasing the number of firms in the market. The increased number of alternatives in a market enables customers to make a comparison between products according to its quality besides the price. To survive in this competitive environment, firms must achieve customer satisfaction by ensuring the optimum in the triangle of time, price, and quality [1].

Usually quality is perceived as 'the quality of final product' but in reality, it brings many benefits to firms, e.g. reduced waste, saved time, increased profit and reduced occupational health and safety problems. Today, successful firms include quality into every level of their production from manufacturing to sales even into the technical support after sales and adopt it as a management philosophy. This philosophy which bases on quality is known as Total Quality Management (TQM).

TQM was firstly adopted in the manufacturing industry, and by the time, it is tried to be adopted in other industries. In the construction industry, unique of each project, variations in labor force, numerous stakeholders, and effect of various parameters such as climatic conditions and formal regulations on the projects make the application of TQM very difficult. According to the literature review, Turkish construction firms don't have sufficient knowledge and experience about TQM and they apply it for prestige purposes [2].

This study aims to investigate the application of TQM in Turkish construction industry, determine critical success factors, barriers and benefits of this application and provide firms with recommendations that asset them to overcome the obstacles by demonstrating the shortcomings in their application. To achieve these aims, a questionnaire survey consisting of four parts has been constructed and answered by firms that wished to participate in this study.

The results of the study show that; in Turkish construction industry the quality is perceived as 'customer satisfaction'; there are short comings in TQM application especially in relation to top management commitment and leadership; the greatest benefit of TQM application is 'increased customer satisfaction'. 


\section{DEFINITIONS of QUALITY}

In the last years, the word 'Quality' has become the slogan of many business organizations. It is used to describe different things in different ways and sometimes it causes misunderstanding. The term 'Quality' has been driven from the Latin word 'quails' that means 'of what kind?' and used to describe specification of a product or service in any sector. The concept of quality is subjective and it means different things to different people, differs from country to country and affected by standard of living, delectation, traditions, social structure and education [3].

Since there is no unified definition of quality, many researchers and organizations try to define quality in different ways $[4,5]$ :

- 'Fitness for purpose or use' - Juran,

- 'Quality is meeting customer's requirements' - Oakland,

- 'Conformance to requirements' - Crosby,

- 'Quality should be aimed at the needs of the consumer, present and future' - Deming,

- 'Degree to which a set of inherent characteristics fulfills requirements' -ISO,

- 'The totality of features and characteristics of a product or service that bear on its ability to satisfy stated and applied needs' - BSI.

- 'The combination of features that based on ability to respond to the product or service requirements' - TSE.

In the construction industry, quality can be defined as 'meeting there quirements of the owner, designer, constructor and regulatory agencies' [6].

\section{TOTAL QUALITY MANAGEMENT (TQM)}

The last stage in the quality evolution is Total Quality Management which involves the understanding and application of quality management principles and concepts in every aspect of business activities. The development of the TQM can be credited to the works of various American experts, e.g. Dr. Edward Deming, Dr. Joseph Juran, and Philip Crosby, who have contributed significantly towards the continuous development of this concept [7].

The easiest way to define Total Quality Management is by analyzing its three single elements: 'Total' the participation of everyone; 'Quality' meeting customer's needs and expectations; and 'Management' the system for achieving qualified products and services [8].

Oakland defines TQM as 'a way of managing to improve the effectiveness, flexibility, and competitiveness of a business as a whole. It applies just as much to service industries as it does to manufacturing. It involves whole companies getting organized in every department, every activity and every single person at every level' $[9,10]$.

British Standards Institution (BSI) defines Total Quality Management as 'A management philosophy and company practices that aim to harness the human and material resources of an organization in the most effective way to achieve the objectives of the organization' [11].

Another definition ISO that states 'TQM is a management approach of an organization centered on quality, based on the participation of all its members and aiming at long-term success through customer satisfaction and benefits to all members of the organization and society' [12].

To avoid misunderstanding, the meaning of 'customer' should be explained. A customer is a person who purchases or supplies the products or services of an organization, and can be categorized as an 
external and internal customer. An external customer is someone who uses your company's products or services but is not a member of your company while the internal customer is the person who works with your company in order to deliver its products or services. It is so important to take care of internal customers to achieve full satisfaction of external customers [13].

\section{PRINCIPLES OF TOTAL QUALITY MANAGEMENT}

The principles of TQM are listed by ISO as follows [14]: customer focus, involvement of people, leadership, continual improvement, factual approach to decision making, process approach, system approach to management, and mutually beneficial supplier relationships.

Kanji and Asher characterized the principles of TQM in a pyramid model and termed it as 'TQM Pyramid'. As it can be seen in Figure 1, the Leadership (management's commitment) constitutes the foundation of this pyramid, and the other principles of TQM: customer focus, focus on facts, continuous improvements and everybody's participation represent the facets of the pyramid [7].

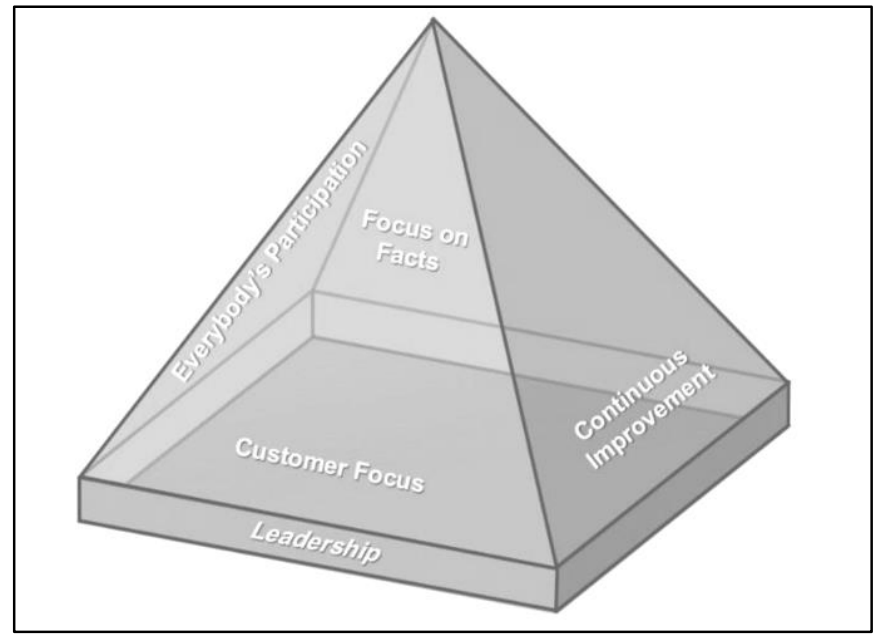

Figure 1. The TQM pyramid [7]

\section{APPLICATION OF TQM IN THE CONSTRUCTION INDUSTRY}

In the Construction industry, achievement of acceptable levels of quality has long been a problem. According to Arditi and Günaydin [6], in each year, there are large expenditures of time, money and resources (both human and material) due to inefficient or non-existent quality management procedures. Recently, the construction companies have started to adopt TQM as an initiative to solve the quality problems, Oakland supported this approach by stating 'If ever an industry needed a take-up for concept of TQM it is the construction industry' [15].

Total Quality Management was firstly adopted in the manufacturing industry and recently it began to be adopted in the construction industry. So, it can be said that construction industry has lagged behind the other industries in adopting TQM. And the reason for this lag were; the perception that TQM belonged to manufacturing industry only, difficulties in measuring (what to measure and how to measure) the results of the continuous improvement process and the perception that application of TQM was costly and required a long period of time [16].

Low and Peh suggested seven basic steps of TQM application in the construction projects which are shown in the Table 1 [17]. 
Table 1. Steps of TQM application in the construction industry

\begin{tabular}{|c|c|}
\hline No. & Steps \\
\hline Step 1 & Obtain the commitment of the client to quality \\
\hline Step 2 & Generate awareness, educate, and change the attitudes of staff \\
\hline Step 3 & Develop a process approach toward TQM \\
\hline Step 4 & Prepare project quality plans for all levels of work \\
\hline Step 5 & Institute continuous improvement \\
\hline Step 6 & Promote staff participation and contribution using quality control circles and motivation programs \\
\hline Step 7 & Review quality plans and measure performance \\
\hline
\end{tabular}

According to Rumane [18], the quality in the construction industry can be achieved by following procedures:

(1) Properly defined scope of work.

(2) Establishment of organizational leadership to achieve the specified quality goals.

(3) Application of continuous improvement at each level by:

- Owner: specify the latest needs.

- Designer: include the latest quality materials, products, and equipment in the specification.

- Constructor: use the latest construction equipment to build the facility.

(4) Establishment of performance measures by:

- Owner: checking and ensuring the satisfaction of contract documents with needs and compliance of work done with these documents.

- Contractor: construct the project according to contract documents by using the materials, products, and equipment that fulfill the specified requirements.

- Consultant: supervise the contractor's work as per contract documents and the specified standards.

(5) Participance of all project team members in the quality improvement process.

(6) Existence of training and education plans for managers, engineers, supervisors, office staff, technicians, and laborers.

\section{MATERIAL AND METHOD}

In order to examine the application of TQM in Turkish construction industry, and identify the critical success factors, barriers, and benefits of this application, Turkish construction firms were selected as the population of this study. Due to budget and time constraints, the construction firms in Turkey's five major cities (İstanbul, Ankara, Bursa, Adana and Konya) were selected as study sample. Among the randomly selected firms, only 32 firms agreed to participate in this study.

For the purposes of this study, a four-part questionnaire survey was prepared by using above mentioned literature. The prepared questionnaire was completed by face to face interviews also, the members of Turkish Cement Manufacturers' Association (TCMA) and Turkish Precast Concrete Association participated in this study by answering the online format of this questionnaire.

A questionnaire survey was structured for the purpose of data collection. This questionnaire consist of four parts. The constructed questionnaire and used evaluation methods is summarized below:

- In the first part of the questionnaire, firstly the demographic characteristics of respondents, such as job, position in the firm, were asked, and then the characteristics of participating firms such as number of employees, field of activity, work sector, work site were asked.

- The second part included multiple choice questions and aimed to examine the respondents' perception about quality and quality management implementations in the firms.

- The third part contained questions concerning the quality management implementations in the firm. In this part, Likert's five points (Strongly Disagree, Disagree, Neutral, Agree and Strongly Agree) scale was used. 
- The fourth part of the questionnaire included questions which are used to identify critical success factors, barriers and benefits of TQM implementation. In this part, factors based on literature [2, $16,19-26]$ were listed and the respondents were asked to rank these factors in the order of importance from 1, most important, to 10, less important.

The collected data of questionnaire was evaluated using the following methods:

- In the first part of the questionnaire, in order to identify the characteristic of participating firms, the number of employees was asked and the firm size was determined by using the criteria of the Table 2. (Small and Medium Sized Enterprises Definition, Qualification and Classification Regulations, [27]).

Table 2. Size of enterprise based on number of employees [27]

\begin{tabular}{|c|c|}
\hline Size of Enterprise & Number of Employees \\
\hline Micro Enterprise & $<10$ \\
\hline Small Enterprise (SE) & $10-49$ \\
\hline Medium Enterprise (ME) & $50-249$ \\
\hline Large Enterprise (LE) & $\geq 250$ \\
\hline
\end{tabular}

- In this study, reliability of the questionnaire was checked using Cronbach's Alpha coefficient $(\alpha)$.

- In this study, data of the questionnaire were firstly analyzed using descriptive statistics such as frequency, percentage, mean and standard deviation, and then the results were discussed.

- In the third part of questionnaire in order to investigate the quality practices of participating firms, the Likert five-point scale was used. The interpretation of this scale is based on the Table 3. [28].

Table 3. Interpretation of Likert's five-point scale [28]

\begin{tabular}{|c|c|c|c|}
\hline Scale & Unit Weight & Weighted Mean Interval & Interpretation \\
\hline Strongly Disagree & 1 & $1.00-1.79$ & Very low level \\
\hline Disagree & 2 & $1.80-2.59$ & Low level \\
\hline Neutral & 3 & $2.60-3.39$ & Medium level \\
\hline Agree & 4 & $3.40-4.19$ & High level \\
\hline Strongly Agree & 5 & $4.20-5.00$ & Very high level \\
\hline
\end{tabular}

In the last part of survey rank ordering questions was used. The interpretation of this scale is based on the Thurstone Scale.Thurstone's Law of Comparative Judgment is a convenient and simple method developed by the psychometrician L.L Thurstone in 1927 and used for analyzing pair-preference and rank-order judgment data [29]. The law consists of five particular cases and the important case is "case V" which will be adopted in this study to analyze the critical success factors, barriers and benefits of TQM implementation in the Turkish construction industry.

The case $\mathrm{V}$ of Thurstone's Law will be explained by the following example: consider there are three brands A, B and C, and we ask a group of individuals to rank these brands in the order of preference from 1 "More Preferable" to 3 "Less Preferable". The ranking data which are illustrated in the Table 4. can be analyzed according to Thurstone's case $\mathrm{V}$ by using the following steps: 
Table 4. Data of ranking example

\begin{tabular}{|c|c|c|c|}
\hline Respondents & Brand A & Brand B & Brand C \\
\hline 1st Respondent & 2 & 1 & 3 \\
\hline 2nd Respondent & 1 & 2 & 3 \\
\hline 3rd Respondent & 3 & 1 & 2 \\
\hline 4th Respondent & 2 & 3 & 1 \\
\hline 5th Respondent & 2 & 1 & 3 \\
\hline
\end{tabular}

\section{Step 1: Construction of Frequency Matrix (F)}

The frequency matrix $(\mathrm{F})$ is prepared depending on the ranking data and represents the frequency of item $\mathrm{i}$ judged to be more preferable than item $\mathrm{j}$. As shown in Table 3., the frequency of brand A judged to be more preferable than brand $\mathrm{B}$ is 2 while the frequency of brand $\mathrm{B}$ judged to be more preferable than brand $\mathrm{A}$ is 3 .

\section{Step 2: Construction of Proportion Matrix (P)}

The Proportion Matrix $(\mathrm{P})$ is constructed by dividing the value of the frequency matrix by the total number of respondents which are 5 in this example. As shown in Table 5., $60 \%$ of the respondents prefer brand B to A, while only $40 \%$ prefer Brand C to A.

Table 5. Proportion Matrix (P)

\begin{tabular}{|l|c|c|c|}
\hline Bi & & & \\
\hline Bj & Brand A & Brand B & Brand C \\
\hline Brand A & - & 0.6 & 0.4 \\
\hline Brand B & 0.4 & - & 0.2 \\
\hline Brand C & 0.6 & 0.8 & - \\
\hline
\end{tabular}

\section{Step 3: Construction of Normal Deviates Matrix (N)}

As shown in Table 6.,the normal deviates matrix $(\mathrm{N})$ is constructed by converting proportion matrix values to the $\mathrm{Z}$ values using standard normal distribution table. After that, the summation of $\mathrm{z}$ values is calculated and divided by the number of items ( 3 brands in this example) to determine the mean of $z$ values, then the absolute of the lowest mean value $(-0.365)$ is added to the mean values.

Tablo 6. Normal Deviates Matrix (N)

\begin{tabular}{|c|c|c|c|}
\hline $\mathbf{B i}$ & & & \\
\hline $\mathbf{B j}$ & Brand A & Brand B & Brand C \\
\hline Brand A & - & 0.253 & -0.253 \\
\hline Brand $B$ & -0.253 & - & -0.842 \\
\hline Brand C & 0.253 & 0.842 & - \\
\hline $\operatorname{Sum} Z$ & 0.000 & 1.095 & -1.095 \\
\hline Mean Z & 0.000 & 0.365 & -0.365 \\
\hline Mean Z+Min & 0.365 & 0.730 & 0.000 \\
\hline
\end{tabular}

\section{Step 4: Construction of Score Table}

The Score table is constructed by arranging the (Mean Z+min) values in descending order (Table 7.) where the highest value indicates the most ranked item. According to the result of analysis, the respondents ranked the brand $\mathrm{B}$ most preferable, followed by brand $\mathrm{B}$ and then $\mathrm{C}$ that can be considered as a less preferable brand. 
Table 7. Score table of brands

\begin{tabular}{|c|c|}
\hline Brands & Score \\
\hline B & 0.730 \\
\hline A & 0.365 \\
\hline C & 0.000 \\
\hline
\end{tabular}

\section{RESULTS AND DISCUSSION}

In this part, results of the reliability analysis; demographic information of the respondents and the profile of their company; descriptive statistics of the questionnaire data and the identified critical success factors, barriers and benefits of TQM implementation are summarized and discussed.

In order to test the reliability of the constructed questionnaire, the Cronbach Alpha coefficient $(\alpha)$ was calculated. The Alpha coefficient $(\alpha)$ of the fourth part of the questionnaire, which consists of rank ordering questions, was not calculated because of "the variance equal to zero" error. The Cronbach Alpha coefficient $(\alpha)$ of the second and third part of questionnaire is 0,875 . According to [30], the Alpha coefficient of 0.875 indicates that the reliability of the questionnaire is good.

The clients' sector of the surveyed firms are given in Table 8 . As shown, $59.4 \%$ of the surveyed firms were operating in both the public and private sectors, and $31.2 \%$ of them in the private sector only while $9.4 \%$ of them were operating in the public sector only.

Table 8. Clients' sector of the surveyed firms

\begin{tabular}{|c|c|c|}
\hline Clients' sectors & Frequency & Percentage (\%) \\
\hline Public \& Private & 19 & $59.4 \%$ \\
\hline Private & 10 & $31.2 \%$ \\
\hline Public & 3 & $9.4 \%$ \\
\hline Total & 32 & $100 \%$ \\
\hline
\end{tabular}

The work site of the surveyed firms is illustrated in Table 9. As illustrated, $75 \%$ of the firms were operating in both local and international sites, $21.9 \%$ of them in the local sites only, and $3.1 \%$ of them were operating in the international sites only.

Table 9. Work site of the surveyed firms

\begin{tabular}{|c|c|c|}
\hline Work sites & Frequency & Percentage (\%) \\
\hline Local \& International & 24 & $75.0 \%$ \\
\hline Local & 7 & $21.9 \%$ \\
\hline International & 1 & $3.1 \%$ \\
\hline Total & 32 & $100 \%$ \\
\hline
\end{tabular}

Table 10. illustrate the activity fields of the surveyed firms. As shown, $90.6 \%$ of the firms were active in the construction and contracting fields, $25 \%$ of them in engineering and project design fields, $15.6 \%$ of them in production of construction materials field and $6.3 \%$ of them in the fields of management and consultancy.

Table 10. Activity fields of the surveyed firms

\begin{tabular}{|c|c|c|}
\hline Activity Fields & Frequency & Percentage (\%) \\
\hline Construction and Contracting & 29 & $90.6 \%$ \\
\hline Engineering and Project design & 8 & $25.0 \%$ \\
\hline Production of construction materials & 5 & $15.6 \%$ \\
\hline Management and Consultancy & 2 & $6.3 \%$ \\
\hline
\end{tabular}


In order to determine the size of the surveyed firms, number of employees in the firm was asked, and the result is illustrated in Table 11. As shown, $71.8 \%$ of the surveyed firms are large-size enterprises and $18.8 \%$ of them are medium-size enterprises while $\% 9.4$ of them are small size-enterprises.

Table 11. Number of employees and size of surveyed firms

\begin{tabular}{|c|c|c|c|}
\hline Size of Enterprise & Number of Employees & Frequency & Percentage (\%) \\
\hline Large Enterprise (LE) & $\geq 250$ & 23 & $71.8 \%$ \\
\hline Medium Enterprise (ME) & $50-249$ & 6 & $18.8 \%$ \\
\hline Small Enterprise (SE) & $10-49$ & 3 & $9.4 \%$ \\
\hline Total & & 32 & $100 \%$ \\
\hline
\end{tabular}

As shown in Table 12., 46.9\% of respondents were civil engineers, $9.4 \%$ administrators, $3.1 \%$ architects and $40.6 \%$ of them were in other professions (mining engineer, environmental engineer, chemical engineer, etc.).

Table 12. Profession of Respondents

\begin{tabular}{|c|c|c|}
\hline Professions & Frequency & Percentage (\%) \\
\hline Civil Engineer & 15 & $46.9 \%$ \\
\hline Business Administrator & 3 & $9.4 \%$ \\
\hline Architect & 1 & $3.1 \%$ \\
\hline Others & 13 & $40.6 \%$ \\
\hline Total & 32 & $100 \%$ \\
\hline
\end{tabular}

The position of respondents in the firm is given in Table 13. As illustrated, $43.8 \%$ of respondents were quality managers, $15.6 \%$ were project managers, $12.5 \%$ are firm managers and $9.4 \%$ of them were site managers while $18.7 \%$ of respondents were in other positions (Human resource manager, department manager and management systems manager).

Table 13. Position of respondents in the firm

\begin{tabular}{|c|c|c|}
\hline Positions & Frequency & Percentage (\%) \\
\hline Quality Manager & 14 & $43.8 \%$ \\
\hline Project Manager & 5 & $15.6 \%$ \\
\hline Firm Manager & 4 & $12.5 \%$ \\
\hline Site Manager & 3 & $9.4 \%$ \\
\hline Others & 6 & $18.7 \%$ \\
\hline Total & 32 & $100 \%$ \\
\hline
\end{tabular}

\subsection{Perception of Quality and Implementation of Quality Management System}

In this part, perception of respondents about quality and implementation of quality management system in the participating firms will be summarized.

\subsubsection{Definition of quality}

As shown in Table 14., most of the respondents defined quality as 'customer satisfaction', which matches the results of Asim [31]. Also, $68.8 \%$ of the respondents perceived quality as 'prestige' and this result is similar to the conclusion of Güner and Giritli [2], which emphasized that in Turkish construction industry quality is used as a trend for prestige purposes. In parallel to this study, Öztaş ve Özbay [32] stated that $34 \%$ of Turkish construction firms perceived quality as 'ensuring quality at every stage of production', $32 \%$ of them as 'customer satisfaction', $24 \%$ as 'faultless products' and $10 \%$ of them perceived quality as ' production of true and faultless products from first time'. 
Table 14. Respondents' definition of quality

\begin{tabular}{|c|c|c|c|c|c|c|c|}
\hline \multirow[b]{2}{*}{$\begin{array}{c}\text { Sample } \\
\text { No. }\end{array}$} & \multicolumn{7}{|c|}{ Quality Definitions } \\
\hline & $\begin{array}{l}\text { Customer } \\
\text { satisfaction }\end{array}$ & Prestige & Teamwork & \begin{tabular}{|l|}
$\begin{array}{l}\text { Increased } \\
\text { profit }\end{array}$ \\
\end{tabular} & Extra costs & $\begin{array}{l}\text { Waste of } \\
\text { time }\end{array}$ & $\begin{array}{l}\text { Other Quality } \\
\text { Definitions }\end{array}$ \\
\hline 1 & + & + & + & + & & & \\
\hline 2 & + & + & + & & + & & \\
\hline 3 & + & + & + & & & & + \\
\hline 4 & + & + & + & + & & & \\
\hline 5 & + & + & & & & & \\
\hline 6 & + & + & + & + & & & + \\
\hline 7 & + & + & & + & & & \\
\hline 8 & + & + & & & & & \\
\hline 9 & + & + & + & + & & & \\
\hline 10 & + & + & & & & & \\
\hline 11 & + & & & & & & \\
\hline 12 & & + & + & & & & \\
\hline 13 & + & + & & & & & \\
\hline 14 & & + & + & + & & & \\
\hline 15 & + & & + & & + & + & \\
\hline 16 & + & & & & & & \\
\hline 17 & + & + & + & & & & \\
\hline 18 & + & + & + & + & & & \\
\hline 19 & + & & & & & & \\
\hline 20 & + & + & + & & & & \\
\hline 21 & + & + & + & + & & & \\
\hline 22 & + & + & + & + & & & \\
\hline 23 & + & + & & + & & & \\
\hline 24 & + & + & + & + & & & \\
\hline 25 & + & + & + & + & & & \\
\hline 26 & + & + & & + & & & \\
\hline 27 & + & & + & + & + & & \\
\hline 28 & + & & + & & & & \\
\hline 29 & + & & & & & & \\
\hline 30 & + & & & & & & \\
\hline 31 & & & & + & & & \\
\hline 32 & & & + & & & & \\
\hline Sum & 28 & 22 & 19 & 15 & 3 & 1 & 2 \\
\hline$\%$ & $87,50 \%$ & $68,80 \%$ & $59,40 \%$ & $46,90 \%$ & $9,40 \%$ & $3,10 \%$ & $6,30 \%$ \\
\hline
\end{tabular}

\subsubsection{Adopted quality principles}

The most adopted quality principles by the surveyed firms were respectively: continual improvement, customer focus, process approach, factual approach to decision making, system approach to management, and involvement of people (Table 15.).

Table 15. Adopted principles of quality management

\begin{tabular}{|c|c|c|}
\hline Quality Management Principles & Frequency & Percentage (\%) \\
\hline Continual improvement & 28 & $87.5 \%$ \\
\hline Customer focus & 24 & $75.0 \%$ \\
\hline Process approach & 23 & $71.9 \%$ \\
\hline Factual approach to decision making & 21 & $65.6 \%$ \\
\hline System approach to management & 21 & $65.6 \%$ \\
\hline Involvement of people & 16 & $50.0 \%$ \\
\hline Leadership & 16 & $50.0 \%$ \\
\hline Mutually beneficial supplier relationships & 16 & $50.0 \%$ \\
\hline
\end{tabular}




\subsubsection{Used quality tools and techniques}

The most used tools and techniques by the surveyed firms were respectively: flow charts, brainstorming, cause and effect diagrams and Pareto analysis. While Dede [33] found that the most used tools and techniques in TQM and innovation are respectively: brainstorming, flow charts, cause and effect diagrams and control charts (Table 16).

Table 16. Quality tools and techniques used by firms

\begin{tabular}{|c|c|c|}
\hline Quality Tools and Techniques & Frequency & Percentage (\%) \\
\hline Flow chart & 19 & $76.0 \%$ \\
\hline Brainstorming & 16 & $64.0 \%$ \\
\hline Cause and effect diagram & 15 & $60.0 \%$ \\
\hline Pareto analysis & 10 & $40.0 \%$ \\
\hline Histogram & 10 & $40.0 \%$ \\
\hline Control charts & 7 & $28.0 \%$ \\
\hline Check sheet & 3 & $12.0 \%$ \\
\hline Scatter diagram & 1 & $4.0 \%$ \\
\hline Nominal Group Technique & 1 & $4.0 \%$ \\
\hline Other tools and techniques & 3 & $12.0 \%$ \\
\hline
\end{tabular}

\subsubsection{Quality management implementations in the firms}

In order to investigate the quality management implementations in the surveyed firms, the implemented quality practices were asked to the participants and the results are summarized in Table 17. According to the results, the most implemented quality management practices were respectively: existence of qualityoriented vision, mission and policies; continuous improvement approach; effective communication between managers and workers; quality based suppliers and subcontractors selection; factual approach to decision making, feedback, continuous measurement of customer satisfaction; and involvement of workers in the decision making process. While the least implemented practices were: top management's leadership and quality education. The average mean of implemented quality practices is equal to (4.16), which indicate that firms had a high level of quality management implementation [28].

Table 17. Quality management implementations in the firms

\begin{tabular}{|c|c|c|c|c|c|c|c|c|}
\hline Practices & $f \& \%$ & S.D & D & $\mathbf{N}$ & $\mathbf{A}$ & S.A & Weighted & Std. \\
\hline \multirow{2}{*}{$\begin{array}{l}\text { In my firm, there are quality-oriented vision, } \\
\text { mission and polices }\end{array}$} & $f$ & 0 & 1 & 1 & 14 & 16 & \multirow{2}{*}{4,41} & \multirow{2}{*}{0,71} \\
\hline & $\%$ & 0,00 & 3,10 & 3,10 & 43,80 & 50,00 & & \\
\hline \multirow{2}{*}{$\begin{array}{l}\text { My firm implements continuous improvement } \\
\text { approach regarding quality }\end{array}$} & $f$ & 0 & 2 & 1 & 11 & 18 & \multirow{2}{*}{4,41} & \multirow{2}{*}{0,84} \\
\hline & $\%$ & 0,00 & 6,30 & 3,10 & 34,40 & 56,30 & & \\
\hline \multirow{2}{*}{$\begin{array}{l}\text { In my firm, there is an effective communication } \\
\text { between managers and workers }\end{array}$} & $f$ & 0 & 1 & 0 & 19 & 12 & \multirow{2}{*}{4,31} & \multirow{2}{*}{0,64} \\
\hline & $\%$ & 0,00 & 3,10 & 0,00 & 59,40 & 37,50 & & \\
\hline \multirow{2}{*}{$\begin{array}{l}\text { In my firm, the selection of suppliers and } \\
\text { subcontractors is based on quality criterion }\end{array}$} & $f$ & 0 & 1 & 3 & 15 & 13 & \multirow{2}{*}{4,25} & \multirow{2}{*}{0,76} \\
\hline & $\%$ & 0,00 & 3,10 & 9,40 & 46,90 & 40,60 & & \\
\hline \multirow{2}{*}{ In my firm decision making is based on facts } & $f$ & 0 & 1 & 1 & 22 & 8 & \multirow{2}{*}{4,16} & \multirow{2}{*}{0,63} \\
\hline & $\%$ & 0,00 & 3,10 & 3,10 & 68,80 & 25,00 & & \\
\hline \multirow{2}{*}{ In my firm, Feedback is performed } & $f$ & 0 & 2 & 2 & 18 & 10 & \multirow{2}{*}{4,13} & \multirow{2}{*}{0,79} \\
\hline & $\%$ & 0,00 & 6,30 & 6,30 & 56,30 & 31,30 & & \\
\hline \multirow{2}{*}{$\begin{array}{l}\text { In my firm, customer satisfaction is } \\
\text { continuously measured }\end{array}$} & $f$ & 0 & 3 & 0 & 19 & 10 & \multirow{2}{*}{4,13} & \multirow{2}{*}{0,83} \\
\hline & $\%$ & 0,00 & 9,40 & 0,00 & 59,40 & 31,30 & & \\
\hline \multirow{2}{*}{$\begin{array}{l}\text { In my firm, workers are involved in decision } \\
\text { making process }\end{array}$} & $f$ & 0 & 2 & 3 & 18 & 9 & \multirow{2}{*}{4,06} & \multirow{2}{*}{0,80} \\
\hline & $\%$ & 0,00 & 6,30 & 9,40 & 56,30 & 28,10 & & \\
\hline \multirow{2}{*}{$\begin{array}{l}\text { In my firm, top managers show leadership for } \\
\text { TQM implementation }\end{array}$} & $f$ & 1 & 3 & 0 & 20 & 8 & \multirow{2}{*}{3,97} & \multirow{2}{*}{0,97} \\
\hline & $\%$ & 3,10 & 9,40 & 0,00 & 62,50 & 25,00 & & \\
\hline \multirow{2}{*}{$\begin{array}{l}\text { In my firm, workers are given sufficient } \\
\text { quality education }\end{array}$} & $f$ & 2 & 3 & 2 & 17 & 8 & \multirow{2}{*}{3,81} & \multirow{2}{*}{1,12} \\
\hline & $\%$ & 6,30 & 9,40 & 6,30 & 53,10 & 25,00 & & \\
\hline
\end{tabular}

* Note: ( S.D: Strongly Disagree, D: Disagree, N: Neutral, A: Agree, S.A: Strongly Agree) 


\subsubsection{Critical success factors of TQM application in Turkish construction industry}

According to Thurstone analysis result (Table 18.), critical success factors that lead to the successful application of TQM in Turkish construction industry were respectively: top management's commitment and leadership, communication between top managers and workers, organizational culture, quality education and employees' involvement. In parallel to this study, Kazemi [21] identified the following critical success factors of TQM in the UK construction industry: top management's commitment, teamwork, effective quality control system and communication between quality department and other departments. While Haupt and Whiteman [34], in their study in the USA construction firms, listed the following critical success factors: top management's commitment and participation, customer focus, effective quality planning and participatory management style.

Table 18. C.S.F of TQM implementation in the order of importance and its corresponding scores

\begin{tabular}{|c|c|c|}
\hline No. & Critical Success Factors & Scores \\
\hline C.S.F 1 & Top management's commitment and leadership & 1.509 \\
\hline C.S.F 4 & Communication between top managers and workers & 1.072 \\
\hline C.S.F 2 & Organizational culture & 1.070 \\
\hline C.S.F3 & Quality education & 1.045 \\
\hline C.S.F7 & Teamwork & 0.928 \\
\hline C.S.F9 & Employees' involvement & 0.736 \\
\hline C.S.F10 & Employees' satisfaction & 0.733 \\
\hline C.S.F8 & Measuring customer satisfaction periodically & 0.581 \\
\hline C.S.F6 & Long-term relationships with subcontractors and suppliers & 0.254 \\
\hline C.S.F5 & Subcontractors and suppliers assessment procedures & 0.000 \\
\hline
\end{tabular}

\subsubsection{Barriers to TQM application in Turkish construction industry}

According to Thurstone analysis result (Table 19), the barriers that faced Turkish firms in during application of TQM were respectively: lack of top-management commitment, perception that application is costly and time-consuming, lack or insufficient education and training, lack of communication between top managers and workers and challenges in changing organizational culture. Haupt and Whiteman [34] listed the barriers of TQM application as many documentation works, lack of involvement of subcontractors and suppliers, low bid subcontractors selection, difficulties in measuring the results and perception of site workers that TQM is unnecessary. While Tey and Ooi [35] identified the barriers to TQM application in Malaysian construction industry as follows: lack of acknowledged personals, low bid subcontractors selection, perception that application is costly and time-consuming and lack of top-management support.

Table 19. Barriers to TQM implementation in the order of importance and its corresponding scores

\begin{tabular}{|c|c|c|}
\hline No. & Barriers & Score \\
\hline B1 & Lack of top-management commitment & 1.009 \\
\hline B3 & Perception that implementation is costly and time consuming & 0.645 \\
\hline B2 & Lack or insufficient education and training & 0.478 \\
\hline B8 & Lack of communication between top managers and workers & 0.436 \\
\hline B9 & Challenges in changing organizational culture & 0.365 \\
\hline B7 & Lack of employees' involvement & 0.336 \\
\hline B10 & Lack of long-term sustainability & 0.179 \\
\hline B6 & The lack of financial and human resources for implementation & 0.132 \\
\hline B5 & Low bid subcontractors selection (low bid mindset) & 0.012 \\
\hline B4 & Many documentation works & 0.000 \\
\hline
\end{tabular}




\subsubsection{Benefits of TQM application in Turkish construction industry}

Thurstone analysis result indicated that (Table 20.) benefits of adopting TQM in Turkish construction industry were respectively: increase in customer satisfaction, decrease in the occupational accidents, reduction in waste, decrease in the defective production and increased productivity. In parallel to this study, Güner and Giritli [2], in their study in Turkish construction industry, listed the benefits of TQM application as follows: increased customer satisfaction, increased quality image of the firm in the market and increased effectiveness of organization, while Polat et al. [23] identified increased customer satisfaction, decrease in the defective production, improved communications between architects, engineers and contractors as benefits of TQM application.

Table 20. Benefits of TQM implementation in the order of importance and its corresponding scores

\begin{tabular}{|c|c|c|}
\hline No. & Benefits & Scores \\
\hline B1 & Increased customer satisfaction & 1.060 \\
\hline B6 & Reduction of occupational accidents & 0.984 \\
\hline B3 & Reduction in waste & 0.906 \\
\hline B4 & Reduction in the defective production & 0.904 \\
\hline B9 & Increased productivity & 0.800 \\
\hline B8 & Timely completion of the project & 0.723 \\
\hline B5 & Increased profit & 0.580 \\
\hline B7 & Increased worker's job satisfaction and motivation & 0.399 \\
\hline B2 & Increased competitive advantage & 0.238 \\
\hline B10 & Increased market share & 0.000 \\
\hline
\end{tabular}

\section{CONCLUSIONS}

The dynamic structure of construction industry, unique of its each project, variations in labour force, and effect of various parameters such as climatic conditions and formal regulations on the projects make the application of TQM in construction industry very difficult. In developing countries, only large-sized firms have quality department and quality professionals, in small and medium-sized firms the quality mangers are selected randomly. In construction site, absence of obligations concern workers' education push the firms to use unqualified labour force which contradicts with principle of TQM 'Quality education to all departments'. Especially the small and medium-sized firms, implement TQM forcibly because of 'Industry pressure' and 'legal obligations' instead of focusing on the long-term benefits of TQM application (such as: increase in customer satisfaction, decrease in the occupational accidents, reduction in waste, decrease in the defective production and increased productivity). As a result, for above reasons the application of TQM in small and medium-sized firms of developing countries is useless.

A number of conclusions have been obtained from this study which aimed to investigate the application of TQM in Turkish construction industry and identify the critical success factors, barriers and benefits of this application. These conclusions can be summarized as follows:

- In Turkish construction industry, the quality was perceived respectively as customer satisfaction, prestige, and teamwork.

- The most important critical success factors of TQM application in Turkish construction industry were respectively: top management's commitment and leadership; communication between top managers and workers; organizational culture; quality education; employees' involvement.

- The barriers that hinder the application of TQM in Turkish construction firms were respectively: lack of top-management commitment; perception that application is costly and time-consuming; lack of or insufficient education and training; lack of communication between top managers and workers; challenges in changing organizational culture. 
- The benefits of TQM application to Turkish construction firms were respectively: increased customer satisfaction; reduced occupational accidents; reduced waste; reduced production deficiencies; increased productivity.

\section{ACKNOWLEDGEMENT}

I also would like to extend my gratitude to Çukurova University Unit of Research Projects (BAP) (Project number: FLY-2015-3802).

\section{REFERENCES}

[1] Shoshan AAA. Application of total quality management in Turkish construction industry, MSc, Çukurova University, Adana, Turkey, 2016.

[2] Güner AF, Giritli H. İnşaat sektöründe toplam kalite yönetimi ve Türkiye'deki uygulamalar. itüdergisi/a, 2004; 3(1): 19-30 (http://itudergi.itu.edu.tr/index.php/itudergisi_a/article/view/1004).

[3] Şimşek M. Toplam Kalite Yönetimi. İstanbul, Turkey: Alfa Publications, 2007.

[4] Oakland JS. Oakland on Quality Management. Oxford, UK: Elsevier Butterworth- Heinemann publications, 2004.

[5] Rumane AR. Quality Management in Construction Projects. New York, USA: CRC Press, 2010.

[6] Arditi D, Günaydin HM. Total quality management in the construction process. InternationalJournal of Project Management, 1997; 15(4): 235-243.

[7] Dahlgaard JJ, Khanji GK, Kristensen, K. Fundamentals of Total Quality Management. London, England: Routledge Publications, 1997.

[8] Ertuğrul İ. Toplam Kalite Kontrol. Ankara, Turkey: Ekin Publications, 2006.

[9] Robson M. Quality Circles: A Practical Guide. Oxford, UK: Gower Publications, 1989.

[10] Pike RJ, Barnes RJ. TQM in Action: A Practical Approach to Continuous Performance Improvement. New York, USA: Springer Publications, 1995.

[11] Hoyle D. ISO 9000 Quality Systems Handbook. Oxford, UK: Butterworth-Heinemann, 2005.

[12] Pfeifer T. Quality Management. Strategies, Methods, Techniques. Munich, Germany: Hanser publications, 2002.

[13] Charantimath PM. Total Quality Management. Chennai, India: Pearson Publications, 2003.

[14] Pyzdek T, Keller P. The Handbook for Quality Management. New York, USA: McGraw- Hill Publications, 2012.

[15] Al-musleh AM. Development of a framework for total quality management principles in the construction companies with special reference to the construction companies in the State of Qatar. $\mathrm{PhD}$, The University of London. London, England, 2010. 
[16] Tang SL, Ahmed SM, Aoieong RT, Poon SW. Construction Quality Management. Pokfulam, Hong Kong: Hong Kong University Press, 2005.

[17] Low SPD, Peh KW. A framework for implementing total quality management in construction, the TQM Magazine, 1996; 8(5), 39-46, DOI: 10.1108/09544789610146033.

[18] Rumane AR. Quality Tools for Managing Construction Projects. New York, USA: CRC Press, 2013.

[19] Metri BA. TQM critical success factors for construction firms, Journal of Contemporary Management Issues, 2005; 10(2), 61-72.

[20] Mahmood WYW, Mohammed AH, Misnan MS, Yusof ZM, Bakri A. Development of quality culture in the construction industry. ICCI, International Conference on Cognitive Informatics, 1719 July 2006; Bejing, China.

[21] Kazemi H. A critical investigation into the implementation of TQM within construction SMEs. 6th International Project Management Conference, 26-27 October, Tehran, Iran, 2010.

[22] Mincks W, Johnston H. Construction Jobsite Management. Boston, USA: Cengage Learning, 2010.

[23] Polat G, Damc1 A, Tatar Y. Barriers and benefits of total quality management in the construction industry: evidence from Turkish contractors. 7th Research/Expert Conference with International Participations, 01-04 June, 2011; Neum, Bosnia and Herzegovina, pp.1115-1120.

[24] Rahman MN, Shokshok MA, ABD Wahab D. Barriers and benefits of total quality management implementation in Libyan manufacturing companies, Middle-East Journal of Scientific Research, 2011; 7(4), 619-624.

[25] Badiru AB. Handbook of Industrial and Systems Engineering. New York, USA: CRC Press, 2013.

[26] Dikko K. Establishing status of Nigerian building design firms based on European construction institute total quality management matrix. 29th Annual ARCOM Conference; 2-4 September, 2013; Belfast, UK, pp. 1037- 1046.

[27] Small and Medium Enterprises Development Organization, www.kosgeb.gov.tr/userfiles/file/kobi_ tanimi. pdf (Date of Visit:23/12/2015).

[28] Çelik G.Türk inşaat sektörü çalışanlarının kişilik özeliklerinin, örgütsel bağlılık ve iş tatmini etkisi. Ph.D., Çukurova University, Adana, Turkey, 2013.

[29] Vavra TG. Improving Your Measurement of Customer Satisfaction. Milwaukee, USA: ASQ Quality Press, 1997.

[30] George D, Mallery P. SPSS for Windows Step by Step: A Simple Guide and Reference. Boston, USA: Allyn \& Bacon, 2003.

[31] Asım M, Zaman S, Zarif T. Implementation of total quality management in construction industry: A Pakistan perspective. Journal of Management and Social Sciences, 2013; 9(1), 24-39, (https://www.researchgate.net/publication/305687276). 
Shoshan and Tantekin Çelik/Anadolu Univ. J. of Sci. and Technology A - Appl. Sci. and Eng. 19 (1) - 2018

[32] Öztaş A, Özbay E. Türk inşaat sektöründe toplam kalite yönetimi açısından değerlendirilmesi, 3. Yapı İşletmesi Kongre Kitabı, İstanbul, Turkey: Maya Matbaacılık, 2005; 484-496.

[33] Dede S. Toplam kalite yönetimi ve inovasyon arasındaki ilişkinin istatistiksel analizi. MSc., Çukurova University, Adana, Turkey, 2012.

[34] Haupt TC, Whiteman, DE. Inhibiting factors of implementing total quality management on construction sites, The TQM Magazine, 2004; 16 (3), 166-173, DOI: 10.1108/09544780410532891.

[35] Tey LS, Ooi TL. Exploring the Barriers and the Level of TQM Implementation in Malaysian Construction Industry, Research Journal of Applied Sciences, Engineering and Technology, 2014; 7(16), 3419-3424 (http://repository.um.edu.my/39392/1/v7-3419-3424.pdf). 